\title{
Good Governance or Local Wisdom? Dilemma in Modern Government Practices in West Sumatra, Indonesia
}

\author{
Asrinaldi $^{1}$, Yoserizal $^{2}$ \\ \{asrinaldi4@yahoo.com ${ }^{1}$, jarjisyoserizal@yahoo.co.id ${ }^{2}$ \} \\ Department of Political Science Universitas Andalas, Padang, Indonesia ${ }^{1}$, Department of Public \\ Administration Universitas Andalas, Padang, Indonesia ${ }^{2}$
}

\begin{abstract}
This article describes the application of Adat Basandi Syarak-Syarak Basandi Kitabullah (ABS-SBK) principle in the application of government in West Sumatera Province. ABS-SBK principle is the norm as well as unwritten law that develops in the life of the people of West Sumatra; the majority are ethnic Minangkabau. ABS-SBK is a form of local wisdom recognized in the implementation of government in Sumatra Province so it becomes one of the development mission that must be implemented in its medium development plan. Interestingly this norm is recognized by the community to control and regulate the implementation of government in West Sumatra Province. Indeed, until now official documents related to the ABS-SBK principle which is the guidance of this development does not yet exist. This article is derived from field research that sees the implementation of development based on this ABS-SBK mission. This study used a descriptive qualitative approach to explain the problems studied. Data were collected through in-depth interviews with some government officials, community leaders and academics who understood the issues under study. In addition, this study also uses secondary data such as government documents, previous research results and news coverage in the mass media to complement the explanation of the analysis derived from field data. This article finds that the people of West Sumatera are not yet able to identify what ABS-SBK principle is applied in government. As a result, local governments are also difficult to describe the development mission that put the ABS-SBK norm as the foundation in the implementation of such development.
\end{abstract}

Keywords: Dilemma, Governance, Local, Wisdom and Development

\section{Introduction}

The administration of government in West Sumatra faces problems with the implementation of existing local values. For example, problems with the implementation of Indigenous philosophy Adat Basandi Syarak-Syarak Basandi Kitabullah (ABS-SBK) in local development. As a norm and value system for Minangkabau ethnic, ABS-SBK philosophy is inseparable from the activities of its citizens [1]-[3]. The implementation of ABS-SBK values can be seen in the community activities in the Nagari even though the actual implementation of ABS-SBK values is only based on different people's habits in each village. The absence of a codification of the ABS-SBK values into the guidelines referred to together has an impact on Minangkabau's understanding of the value of ABS-SBK. The same can be seen from the regional government work plan (RKPD) which has not yet referred to the ABS-SBK value. 
It is commonly known that the social and cultural values of a society are believed to influence the implementation of development. This social and cultural value becomes the guideline for the community in their activities even though this social value is not written in an official document. If the development carried out refers to the value of ABS-SBK developed in the community, then the development carried out is easier to implement. That is, the cultural dimension of society influences the success of the development carried out [4]. In the micro context, the influence of this culture on one's beliefs and choices on economic outcomes [5].

The Regional Government of West Sumatra Province is also bound by a medium-term development plan (RPJMD) which contains the value of ABS-SBK as one of the principles for implementing development. Although from one side, the principles of governance must be applied in the implementation of the development function. The application of the principles of governance must start from the planning, implementation, and evaluation of development programs. This is intended so that the development goals are by the interests of the community. However, from the other side, the regional government must also consider cultural values in the local community because governance does not only look at the role of the state as a development actor, but also the involvement of non-state actors that contribute to the success of the development [6].

This paper describes how the West Sumatra regional government makes cultural factors and principles of governance as a principle in carrying out development. As is well known, this cultural value is the first mission in the West Sumatra mid-term development plan (RPJMD) for the period of 2016-2021. This mission focuses on "improving the harmonious, religious, civilized, and cultured way of life-based on the ABS-SBK philosophy." Moreover, the West Sumatra regional government does require the application of the ABS-SBK value so that it can influence the implementation of other programs. However, this effort is not easy because of the many obstacles in its implementation. Even the regional government of West Sumatra Province faces a dilemma of how to implement development based on cultural values while implementing governance, especially in making development programs.

The main argument of this paper departs from the unclear value of ABS-SBK that can be used as a reference in the implementation of development by the West Sumatra regional government. This fact can be seen from the absence of a special document that contains the ABS-SBK philosophy as a basis for development in the region. Likewise with the function of religious and customary institutions to guard and preserve the value of ABS-SBK that has not been implemented properly. 


\section{Good Governance in Modern Government}

Modern government in carrying out its functions refers to the principles of good governance. The World Bank currently introduces the term Good Governance used by many governments. Starting from a meeting involving many leaders of developed countries in 1992 resulted in an agreement known as the Washington Consensus. This meeting saw the need for a collective agreement so that the recipient countries from donor countries in carrying out development by the principles of good governance [6]. The concept of good governance includes several main principles, namely accountability, transparency, participation, responsiveness, the rule of law, equality, strategic vision, and effective and efficient.

The Indonesian government also uses the principle of governance in development practices. For example, in the implementation of regional autonomy in the early 2000s, the concept of governance became an indicator of the best practices of governance. The application of this governance principle is very reasonable. Because all this time the implementation of development cannot be separated from the problem of corruption so that the quality of development produced is far from the expectations of the community [7]. Almost all developing countries face similar problems [8].

Even the poor governance in developing countries is also a concern of the World Bank. Many governments in developing countries have failed to develop their countries because of poor governance. The impact is the low quality of community welfare due to the poor development produced even though the assistance disbursed by the World Bank to developing countries is always increasing from year to year. However, many were lost due to the corruption committed by state administrators. Many parties understand the effective way to improve this condition is by applying the principles of good governance.

\subsection{Governance and Local Values}

Governance is certainly not in a vacuum. The application of good governance principles is in the community. People usually live with a cultural system that can help them achieve their common goals. For example, this cultural system also determines the success of the development. The West Sumatra regional government always pays attention to the cultural system that exists in the community so that the development carried out has maximum support. This can be seen from the ninik mamak involvement in implementing development planning meetings (Musrenbang). What ninik mamak has done indirectly gives legitimacy to the Nagari guardian to implement the development proposed through the Musrenbang.

Basically this cultural system of society does not conflict with the principles of modern governance. However, in practice, the implementation of governance has not been fully implemented. The basis of kinship that is part of the social and cultural values of the Minangkabau ethnic community is often faced with the principle of impersonality in the modern bureaucracy. This reality is very easy to find, especially in public services in the Nagari and regency/city. Of course, it is not easy for local government officials when they have to serve their consanguine personally. Meanwhile, the modern bureaucracy prioritizes the principle of impersonal public service. It is the fact that cultural values can also deal with modern governance.

The next issue that also becomes a dilemma for local governments is when they have to use this cultural system as a basis for the implementation of development. By Law No. 25 of 2004 concerning the national development planning system, this planning is the basis for developing programs and activities of development. One of them is through participatory development planning. Participatory planning is the involvement of the community as development actors 
who determine the program according to their interests. The mechanism is through Murenbang which is carried out periodically and in stages ranging from the neighborhood to the district/city. Even so, not all community proposals can be accommodated into the RKPD and entered into APBD financing. Many residents are disappointed with this Musrenbang process because the government does not finance their development program proposals. Whereas their involvement in the Musrenbang also reflects their togetherness to reinforce social and cultural values.

\subsection{ABS-SBK Philosophy and Development Program}

It is difficult to identify when the ABS-SBK philosophy is used as a basis for the life of the Minangkabau ethnic group. Referring to Tambo, since the entry of Islam brought by Aceh traders into the Minang realm, then at that time an agreement was made between Aceh traders who developed Islam in the Minang realm with the indigenous people so that their customs and culture were not lost due to this interaction. It is where the emergence of the relationship between religion and adat with the customary philosophy of Adat Basandi Syarak, Syarak Basandi Kitabullah, Syarak Mangato, Adat Mamakai (Adat Basandi Syarak, Syarak Basandi Kitabullah, Syarak mentioned, the custom employs).

However, in some books, for example, Rusli Amran asserts that the ABS-SBK philosophy has emerged since the end of the Paderi War which lasted for 30 years [9]. The end of the war between the Paderi and the adat is marked by an agreement between the two parties which is formulated in Marapalam Hill Lintau Buo, Tanah Datar Regency. This agreement is also known as the Sumpah Satie Bukik Marapalam which is the basis for the implementation of the Adat Basandi Syarak, Syarak Basandi Kitabullah. Syarak Mangato, Adat Mamakai. Since then the ABS-SBK philosophy has become the basis for the lives of Minangkabau ethnicity to this day.

Although the ABS-SBK Philosophy is the basis of every activity of the Minangkabau community, its implementation is far from what is expected. Even the local government has difficulty measuring the extent to which the implementation of ABS-SBK philosophy can be implemented in people's lives. In the regional action plan (RAD) of the ABS-SBK movement which is a description of the RPJMD, it still uses performance indicators of local government institutions rather than referring to the practice of individuals in the community.

This cultural value system can encourage people to act by common interests. Because in the Minangkabau ethnic culture system contains values that can encourage individuals to act for the good of the community and themselves [10]. This tendency can be compared with the emergence of individual beliefs that influence their motivation to act by their rational interests as described by Max Weber with his work The Protestant Ethic and the Spirit of Capitalism. Weber believes that Protestant ethical values influence the way individuals try to accumulate wealth for investment through their economic behavior. So with the existence of Protestant ethics that individuals practice can drive capitalism in Europe and even the world. Weber proved that Protestant followers tend to pursue rational economic motives and develop positive moral values for the development of the spiritual aspects they believe in [11].

In Weber's understanding related to the Protestant ethics, this can be analogous to aspects of ABS-SBK practice by Minangkabau ethnic groups. If adat is carried out as an individual value system in action, of course, social problems that arise in the community will not be found. Moreover, this customary value system is the foundation of the Qur'an and Sunnah has become the main belief of the Minangkabau people. However, the fact is that this is not the case, precisely the implementation of ABS-SBK has not been fully found in everyday reality. How could this happen?

For Minangkabau ethnic, ABS-SBK philosophy is the main foundation for them to carry out their daily activities. The ABS-SBK philosophy is recognized as a comprehensive 
philosophy because it combines Islamic values as Minangkabau ethnic beliefs with Minangkabau customs as a result of their intentions and reason. The nature of ABS-SBK philosophy is the custom of savanna nan in Minangkabau society [12]. Therefore, it is not surprising that the combination of the two is seen in the ABS-SBK philosophy which is recognized as the grand work of Minangkabau ethnic civilization. Because the ABS-SBK philosophy is the belief of the Minangkabau people, there is an urge to make this ABS-SBK philosophy as the basis for governance.

Even so, it is not an easy matter for the regional government to describe the ABS-SBK philosophy into the implementation of its functions in the community. The problem is that the ABS-SBK philosophy values are not yet clear so it is difficult to translate it into development programs. Indeed, there are several programs compiled in the RKP and APBD of the West Sumatra Provincial Government. However, the foundation for implementing these programs and development activities has not touched the substance of the ABS-SBK philosophy.

\section{Method}

This article is the result of field research conducted in Solok Regency, South Pesisir Regency, Tanah Datar Regency and Padang Pariaman Regency. The selection of this region is based on the consideration of two regional characteristics known in the government system in West Sumatra, namely the darek area (land) and the rantau (coastal) region which certainly affects the implementation of the ABS-SBK philosophy. First, the region of Darek is an area that has relatively homogeneous characteristics of society with strong cultural values and slightly undergoes changes due to modernization such as Solok Regency and Tanah Datar Regency. Second is the overseas region which tends to have heterogeneous and pluralistic societies with open and loose cultural values due to modernization. Therefore, the community can accept the entry of new values such as the Padang Pariaman Regency and Pesisir Selatan districts. This study uses a descriptive qualitative approach to explain the phenomenon of ABSSBK values in development. Data is collected through in-depth interviews with some figures such as those who understand customs, religion, government, local academics and the informal elite outside of the above. In addition, secondary data derived from various relevant documents are also used in analyzing the problem under study. The implementation of this research was conducted from April to July 2018.

\section{Result and Discussion}

Philosophy of Adat Basandi Syarak-Syarak Basandi Kitabullah (ABS-SBK) became the mission of the Regional Medium Term Development Plan (RPJMD) in West Sumatra. Except for Mentawai Islands regency, there are 18 other districts and cities in West Sumatra outlining the mission contained in the RPJMD into government programs and activities. This can be seen in the programs contained in the RPJMD of the West Sumatra Provincial Government, for example increasing understanding, appreciation, practice, and development of religious values. Especially in the Province of West Sumatra, where the majority of the population is Muslim, the basis of the Minangkabau ethnic customs and culture is the Qur'an and Sunah. In addition, the program in implementing ABS-SBK can also be seen from the development of cultural values, and the development of indigenous institutions in the community [13]. 
Interestingly, this program has a general tendency and has not been elaborated explicitly into development activities that are by the substance of the ABS-SBK philosophy value. The problem is that there is no clear guidance regarding the substance of ABS-SBK values that guide local government officials to describe existing programs into relevant development activities. Even in practice, the preparation of local government programs based on the ABS-SBK mission tends to be interpreted only by local government organizations (OPD). As long as it has something to do with religious and cultural issues in people's lives, the activities made are considered relevant and support the implementation of the ABS-SBK philosophy values. Obviously this has implications for development programs and activities that are made not oriented to social and cultural issues in society.

In theory, in making the development program begins with planning activities. Planning is an important part in the preparation of development programs so that the results of development can be evaluated by the documents used such as the RPJMD that has been previously determined. Usually, the local government describes the programs contained in the RPJMD into the RKP that have been prepared by the OPD that compiled the development activities. In addition, through this development planning, supervision and control of the programs implemented will be easy to do [14].

In addition, in the non-formal context, there are also proposals outside government institutions compiled by the community. The development proposal is intended to support development planning that has been prepared by the regional government - for example, development planning documents derived from the cultural values of local communities which in the preparation also involve non-governmental organizations. Of course, there are a lot of proposed activities that come from this community so that a selection is needed to fit the existing RPJMD document. Even so, the proposal to strengthen the ABS-SBK philosophy in the form of documents as a foundation for the development of community cultural development programs is not yet available. As a result, the Bappeda as the government body that prepares development planning has not been able to refer to documents explaining how the ABS-SBK philosophy is actually translated into a development program.

The problem that is often faced by local governments in making development programs is the lack of focus on program preparation according to the needs of local communities. Usually, the community, especially in rural areas, assesses the success of the program made by this government if it refers to the local cultural system. Meanwhile, the government compiled the program refers to the rules made by the central government. For example, governance is oriented towards good governance. One of the spirits in this governance is how to implement this government effectively and efficiently. In addition, the government is also oriented to public services that are responsive and by the needs of the community. Even encouraging the public to be actively involved in the main value in realizing accountability and transparency in the administration of the government [15].

The insistence of the people of West Sumatra to include cultural values as a foundation for development encourages local governments to incorporate these local cultural dimensions into relevant programs. However, the problem is what kind of references can help local governments describe the program not yet available. Although the provincial government of West Sumatra also included some programs, it was not by what was expected by the community. It is the dilemma faced by the West Sumatra provincial government in carrying out development based on that cultural value. Indeed, development success can be achieved if the planning refers to the cultural values that develop in the community. Moreover, integrating a development approach that takes into account the social and cultural environment of society with the principles of the 
implementation of modern governance is the basis of the development approach in many countries [16].

The absence of guidelines that can be used as a reference, the success of ABS-SBK implementation in the development program is also influenced by the role of syarak and adat institutions that have not been going well. Moreover, it was pointed out by many parties, all this time the syarak and adat institutions had lost their function. This can be seen from the activities of syarak and adat institutions which tend to only carry out ceremonial activities, for example, awarding of traditional titles which are attended by government figures. Whereas religious and customary issues in the lives of anak-kemanakan in tribes are increasingly complex. The weak function of the syarak institutions and adat institutions also influences the compilation of the ABS-SBK philosophy document that can be used by local governments. Another weakness is that each of these institutions has not been able to work together in coordinating their activities, especially in carrying out their functions.

Syarak and adat institutions that oversee the implementation of ABS-SBK such as the Minangkabau customary consultative body (LKAAM) and the Indonesian Scholar Council (MUI) of West Sumatra have not functioned properly. Even the institutional functions of LKAAM at the district level and MUI have not optimally carried out their functions. As a result, the implementation of ABS-SBK values in the lives of Minangkabau people cannot be implemented. One of the causes of LKAAM and MUI malfunctions in the community is due to the dependence of financing of these two institutions on funds provided by the local government.

In principle, between the teachings of Islam and the Minangkabau customs have been combined for a long time so that it is difficult to separate from one another. This combination of values is the basis for Minangkabau ethnic groups to behave in a community environment [17]. Although in reality, not all Minangkabau people know exactly what cultural values are contained in the ABS-SBK philosophy. Moreover, lately it is alleged that this young generation is further away from the teachings of Minangkabau customs and culture. This fact is also considered as a problem why the ABS-SBK philosophy has not fully grown and developed in the lives of the young generation of Minangkabau ethnicity.

According to government officials in the West Sumatra region, the absence of sharia and adat institutions that carry out their functions properly is also a problem in strengthening the implementation of development programs and activities. Many development programs in the APBD have not supported development targets, especially strengthening the development of the ABS-SBK values. For example, in 2017 the Provincial Government of West Sumatra through the Department of Culture allocated a budget of Rp. 1,611,484,643 for strengthening and developing cultural values. In addition, it also budgeted Rp. 399,022,854 for the development program of cultural values. It can be understood that the two activities have almost the same results so that it seems redundant. If this department of cultural can coordinate this program with syarak and adat institutions, of course a program will be produced that leads to the strengthening of these cultural values.

Especially if it is associated with the purpose of the activity carried out it turns out that it has not touched the strengthening of existing syariah and adat institutions. This has become a dilemma, on the one hand the local government is required to be responsive to the needs of the community as is the principle of implementing good governance. However, on the other hand, the government needs input and cooperation from the syarak and adat institutions to improve the programs and activities that they form to suit the interests of the local community. The absence of coordination between the two institutions is clearly a crucial problem for local governments in realizing good governance. 
The weak implementation of the ABS-SBK philosophy in the implementation of this development is also known from the low commitment and consensus of the community to implement it. Even if there is a strong commitment from the community in implementing the value of the ABS-SBK philosophy, then the substance of the Abs-SBK value will be found. These values will be the reference for the regional government in planning development programs. However, because the value of ABS-SBK is not clear, it affects the performance of local governments in implementing development programs, especially reinforcing the ABSSBK philosophy values.

Therefore, it is not surprising; local governments tend to use the principles of governance rather than referring to the cultural values of the existing society. Even so, the traditional Minangkabau elite recognizes that the principles of good governance are in line with the existing ABS-SBK philosophy. This ABS-SBK Philosophy value can be traced from the plots or in the traditional customs that exist in Minangkabau culture. In the following table, we can see the suitability of the values between the principles of governance and the ABS-SBK philosophy derived from the Minangkabau culture.

However, the question is, can the cultural values contained in adat planners be a reference in the implementation of development? Most Minangkabau people do use ABS-SBK philosophy as a guide for their lives. However, in the administration of the regional government, adat planners alone are not enough to help local governments make it a reference for realizing government goals. Especially in the implementation of modern governance at the local level, the principle of governance is a necessity followed by government officials. Meanwhile, the ABS-SBK philosophy values that want to be used as the basis for the implementation of development programs are not yet known so that they can be used in the implementation of regional governance.

This problem is indeed a dilemma for local governments to carry out their functions, especially development. On the one hand, the practice of this government is in the reality of Minangkabau people who do practice their social and cultural systems. While on the other hand, the desire to combine the ABS-SBK philosophy with the principles of good governance has never been realized whereas the ABS-SBK philosophy is the first mission in the RPJMD which is indeed the main document of development planning that must be referred by local government organizations.

Table 1. The relationship between the principles of good governance and the Minangkabau ABS-SBK philosophy

\begin{tabular}{|c|c|}
\hline Good Governance & ABS-SBK Philosophy \\
\hline Accountability & $\begin{array}{l}\text { Diagak mangko diagiah, dibaliak mangko dibalah (Responsible } \\
\text { for the work done with a mature plan) }\end{array}$ \\
\hline Transparency & $\begin{array}{l}\text { Putiah kapeh dapek diliek, putiah hati bakadaan (White cotton } \\
\text { can be seen, white heart is in shape) }\end{array}$ \\
\hline Participation & $\begin{array}{l}\text { Duduak surang basampik-sampik, dua basamo balapang-lapang } \\
\text { (Everything that involves a large number of people facilitates the } \\
\text { work done) }\end{array}$ \\
\hline Effective and efficiency & $\begin{array}{l}\text { Gadang agiah baonggok, ketek agiah bacacah (Distribution } \\
\text { according to the allocation that has been set) }\end{array}$ \\
\hline Responsive & $\begin{array}{l}\text { Alun disuruah inyo lah pai, alun diimbau inyo lah datang (He } \\
\text { hasn't been told to leave, hasn't been called up yet) }\end{array}$ \\
\hline Equality & $\begin{array}{l}\text { Mandapek samo balabo, kahilangan samo barugi (Cooperate in } \\
\text { carrying out joint tasks) }\end{array}$ \\
\hline
\end{tabular}


Startegic vision

The rule of law

Inklusivitas
Kiro-kiro indak sakali datang, pangana indak sakali tumbuah (Consideration does not come once, memory does not grow once) Alua samo dituruik, limbago samo dituang (obey the rules that are made together)

Dima indak ado alang, disinan bilalang jadi rajo (Where there are no eagles, there grasshoppers become kings)

Source: Processed from various sources

\section{Conclusion}

It is not easy for local governments to realize the first mission of development in the West Sumatra RPJMD for the 2016-2021 period. All the more describes it in the work plan of the regional device organization. The reason is that there are no guidelines related to the elaboration of the ABS-SBK philosophy that can be referred by government institutions. Another problem is the lack of coordination between syarak and adat institutions in carrying out their functions to guard the implementation of ABS-SBK philosophy in the lives of Minangkabau people. Although the local government has tried to elaborate on this first mission into the development program, what is still referred to is the principle of good governance as regulated in the local government law. It can be concluded that what stands out in implementing the development function is only the implementation of the principles of governance rather than referring to the ABS-SBK philosophy as in the first mission in the West Sumatra provincial mid-term development plan.

\section{Acknowledgment}

This research can be carried out because it is funded by the Ministry of Research, Technology and Higher Education through a research grant program in 2018.

\section{References}

[1] Asrinaldi, 2017, Demokrasi Lokal di Indonesia: Otonomi, Nagari dan Sosial Budaya di Sumatera Barat. Padang: Erka Publishing.

[2] Hadler, Jeffrey, 2010, Sengketa Tiada Putus: Matriarkat, Reformisme Islam, dan Kolonialisme di Minangkabau. Terjemahan: Samsudin Berlian. Jakarta: Freedom Institute.

[3] Navis, AA., 1984, Alam Takambang Jadi Guru: Adat Kebudayaan Minangkabau. Jakarta: Grafiti Pers.

[4] Petrakis, Pangiotis E., 2014. Culture, Growth, and Economic Policy, New York: Springer.

[5] Guiso, Luigi, Sapienza, Paola \& Zingales, Luigi, 2006. "Does Culture Affect Economic Outcomes?", Journal of Economic Perspectives 20 (2), pp. 23-48.

[6] World Bank, 2017, World Development Report: Governance and the Law. Washington D.C: The World Bank.

[7] Setiyono, Budi, 2014, "Does Governance Reform in a Democratic Transition Country Reduce the Risk of Corruption? Evidence from Indonesia. In R.N. Ghosh \& M.A.B. Siddique (Eds.), Corruption, Good Governance and Economic Development: Contemporary Analysis and Case Studies. London: World Scientific Publishing.

[8] Lindsey, Tim, 2002, "Hitory Always Repeats? Corruption, Culture and 'Asian Values', in Tim Lindsey \& Howard Dick (Eds.). Corruption in Asia: Rethinking the Governance Paradigm, New South Wales: The Federartion Press.

[9] Amran, Rusli, 1981. Sumatera Barat Hingga Plakat Panjang. Jakarta: Sinar Harapan. 
[10] Hakimy, Idrus, 2001, Pokok-Pokok Pengetahuan Adat Alam Minangkabau. Cetakan ke-8. Bandung: Rosdakarya.

[11] Weber, Max. 1992. The Protestant Ethic and the Spirit of Capitalism. Terj. Talcot Parson. New York: Routledge.

[12] Abidin, Mas'oed, 2016, Tiga Sepilin: Surau Solusi Untuk Bangsa. Yogyakarta: GRE Publishing.

[13] Bappeda, 2017, Evaluasi Kinerja Pembangunan Daerah Tahun 2016, Padang: Bappeda Provinsi Sumatera Barat

[14] Syafrizal, 2017, Perencanaan Pembangunan Daerah Dalam Era Otonomi, Jakarta: Rajawali Press.

[15] Khairuddin, Ahmad, 2010, "Fenomena Keadilan Dalam Otonomi Daerah", in Bungaran A. Simajuntak (Ed.), Otonomi Daerah, Etnonasionalisme dan Masa Depan Indonesia. Jakarta: Yayasan Pustaka Obor Indonesia.

[16] Woolcock, Michael, 2014, "Culture, Politics and Development", Policy Reserach Working Paper 6939, pp.1-21, Washington D.C.: The World Bank.

[17] Zainuddin, Musyair, 2008, Implementasi Pemerintahan Nagari Berdasarkan Hak Asal-Usul Adat Minangkabau. Yogyakarta: Penerbit Ombak. 